Citation: E.M. Kalvelage, R.T. Voegele, M. Fischer (2021) Dissemination of esca-related pathogens in German vineyards: do arthropods play roles in vectoring spores?. Phytopathologia Mediterranea 60(3): 467-478. doi: 10.36253/phyto-12948

Accepted: October 10, 2021

Published: December 30, 2021

Copyright: (c) 2021 E.M. Kalvelage, R.T. Voegele, M. Fischer. This is an open access, peer-reviewed article published by Firenze University Press (http:// www.fupress.com/pm) and distributed under the terms of the Creative Commons Attribution License, which permits unrestricted use, distribution, and reproduction in any medium, provided the original author and source are credited.

Data Availability Statement: All relevant data are within the paper and its Supporting Information files.

Competing Interests: The Author(s) declare(s) no conflict of interest.

Editor: Jose R. Urbez Torres, Agriculture and Agri-Food Canada.

\section{Research Papers \\ Dissemination of esca-related pathogens in German vineyards: do arthropods play roles in vectoring spores?}

\author{
Elisa Maria KALVELAGE ${ }^{1,2, *}$, Ralf Thomas VOEGELE ${ }^{2}$, Michael \\ FISCHER $^{1}$ \\ ${ }^{1}$ Julius Kühn-Institute (JKI), Institute for Plant Protection in Fruit Crops and Viticulture, \\ Siebeldingen, Germany \\ ${ }^{2}$ Institute of Phytomedicine, University of Hohenheim, Stuttgart, Germany \\ ${ }^{*}$ Corresponding author. E-mail: elisa.kalvelage@julius-kuehn.de
}

Summary. Grapevine Trunk Diseases (GTDs) such as esca challenge viticulture. The main fungal agents of Petri disease or young esca, Phaeomoniella chlamydospora (Pch), diverse Phaeoacremonium species (Pm spp.) and Cadophora luteo-olivacea (Clo), are transmitted to pruning wounds of vines by rain splashes and air currents. Arthropodmediated dispersal is another possibility for the pathogens to reach pruning wounds. The present study was the first to evaluate possible involvement of arthropods in the dissemination process of esca-related pathogens in German vineyards. Diversity of arthropods on grapevine trunks was determined in 2019 and 2020, using cardboard traps mounted on vine trunks. Captured arthropods were surveyed for the presence of esca-related pathogens on their exoskeletons by using a nested multiplex PCR. In total, 2099 arthropods were examined, of which 35\% were positive for Phaeomoniella chlamydospora (Pch), $21 \%$ for Phaeoacremonium spp. (Pm), and 7\% for Cadophora luteo-olivacea (Clo). Earwigs and spiders were the most prevalent trapped arthropods; Pch was detected on $27 \%$ of earwigs and $38 \%$ of spiders, Pm spp. on 17 and 19\%, and Clo on 3 and $8 \%$ of these arthropods. In both years, arthropods carrying the pathogens were already present in April, and therefore within the presumed susceptibility phase of pruned vines. These results indicate involvement of arthropods in the dispersal of esca-related pathogens in German vineyards. Further research, particularly to determine the infection potential of insect-borne fungi, is needed to confirm transmission risk. These results underline the importance of protecting vine pruning wounds to prevent host invasion by GTD pathogens.

Keywords. Grapevine trunk diseases, Phaeomoniella chlamydospora, Phaeoacremonium spp., Cadophora luteo-olivacea, dispersal, pruning wounds.

\section{INTRODUCTION}

Grapevine health is severely affected by Grapevine Trunk Diseases (GTDs). According to symptomatology of leaves, berries and wood, and in relation to a variety of wood-inhabiting fungi, GTDs can be subdivided into different diseases or syndromes (Mugnai et al., 1999; Bertsch et al., 2013; Fontaine et al., 2016; Mondello et al., 2018). All of these cause general deteri- 
oration of vine vascular systems eventually reducing the production and longevity of vineyards (Vasquez et al., 2007; Hofstetter et al., 2012; Lecomte et al., 2012).

Esca is one of the most important GTDs, and is a disease complex related to distinct symptoms, pathogens and vine age. This includes the so-called grapevine leaf stripe disease (GLSD, previously known as "young esca"), characterized by "tiger-stripes" on host leaves, which is the most important and widespread GTD (Mugnai et al., 1999; Surico, 2009; Mondello et al., 2018). Others include brown wood streaking, Petri disease (black goo or slow dieback), "vine apoplexy" or "acute esca", and "esca proper" (including white rot, caused by Fomitiporia mediterranea; Fischer, 2002). Co-existence of GLSD and "esca proper" is a widespread phenomenon in old vineyards. To complicate matters, all of these diseases may overlap, and also occur with other canker agents such as Botryosphaeriaceae and/or Diatrypaceae (Rolshausen et al., 2010; Gramaje et al., 2018; Moyo et al., 2018). In addition, these diseases are often cryptic and symptoms may take several years to develop (Surico et al., 2000; Surico et al., 2006; Christen et al., 2007).

Crucial for all early stages of esca are trachaeomycotic fungi, including Phaeomoniella chlamydospora (Pch) (Crous and Gams, 2000), Phaeoacremonium spp. (Pm spp.) (Mostert et al., 2006) and, possibly, Cadophora spp. (Halleen et al., 2007; Gramaje et al., 2011; Travadon et al., 2014). In German vineyards, besides the frequently occurring $P c h$, diverse $P m$ spp. such as $P m$. fraxinopennsylvanicum, Pm. viticola and, above all, Pm. minimum have been isolated from symptomatic grapevines (Fischer and Kassemeyer, 2003; Fischer et al., 2016; Kraus et al., 2019). Among Cadophora, C. luteo-olivacea (Clo) was the most frequent species (Fischer et al., 2016; Haag, 2018; Fischer, 2019; Kraus et al., 2019).

For all vine-growing regions, pruning wounds are considered as major entry points for esca-related pathogens (Larignon and Dubos, 1997; Mugnai et al., 1999; Larignon and Dubos, 2000; van Niekerk et al., 2011). Susceptibility of pruning wounds in California to Pch and Pm. minimum was found to last for up to 4 months (Eskalen et al., 2007), and in Spain susceptibility to Pch was found to last for up to 12 weeks (Elena and Luque, 2016). Sucker wounds caused by vineyard management may also be entry points for the pathogens (Makatini, 2014).

Concerning the inoculum sources, Pch was observed abundantly sporulating in cracks of vine bark (Edwards et al., 2001), and fruit bodies of Togninia minima, the teleomorph of Pm. minimum (Mostert et al., 2003), were found in wood crevices of diseased vine trunks (RooneyLatham et al., 2005b; Baloyi et al., 2013). Dispersal of all these fungi is by airborne spores in rain splashes or carried by wind (Larignon and Dubos, 2000; Eskalen and Gubler, 2001), and this is also likely for Clo (Gramaje et al., 2011). In German vineyards, the presence of airborne $P c h$ inoculum has been repeatedly verified by isolation or molecular detection from spore traps (Haag, 2018; Kraus et al., 2020; Molnar et al., 2020).

Arthropods including spiders, ants, and millipedes have been demonstrated as vectors for Pch, Pm spp. and other GTD-related pathogens in South Africa (Moyo et al., 2014). The possible significance of arthropods in the transmission of several plant diseases has long been accepted (Leach, 1940). One prominent example for arthropod-mediated dispersal is the association of bark beetles and Ophiostoma novo-ulmi, the cause of the Dutch elm disease (Brasier, 1991).

No previous studies have surveyed the possible involvement of arthropods in the dispersal of esca-related pathogens in German vineyards. With a focus on the relationship between pruning measures and epidemiology of esca-related pathogens, the aims of the present study were to determine: i) the occurrence and diversity of arthropods on vine trunks in Germany; and, specifically, ii) the occurrence and identification of Pch, Pm spp. and Clo on arthropod exoskeletons.

Results from this study provide new information about the epidemiology of esca-related pathogens and may eventually contribute to enhancing measures to reduce the spread of esca, mostly so with regard to an efficient protection of pruning wounds.

\section{MATERIALS AND METHODS}

\section{Sampling sites}

Arthropod diversity was assessed in 2019 and 2020 in experimental vineyards located at the Julius KühnInstitute in Siebeldingen, Germany. Two vineyards of different ages, cultivars and management practices were chosen. Vineyard "A" $\left(49^{\circ} 13^{\prime} 00.2^{\prime} \mathrm{N}\right.$; $\left.8^{\circ} 02^{\prime} 53.1^{\prime} \mathrm{E}\right)$ was planted in 1996, and vineyard " $\mathrm{B}$ " $\left(49^{\circ} 13^{\prime} 08.8^{\prime}\right.$ " $\mathrm{N}$; $\left.8^{\circ} 02^{\prime} 39.6^{\prime \prime} \mathrm{E}\right)$ was planted in 2002. Vineyard "A" contained the fungus-resistant (PIWI-) cultivar Vitis vinifera cv. 'Phoenix' and was chosen because of the high incidence of GLSD-symptoms and apoplexy observed in previous years (Molnar et al., 2020). Vineyard "B" comprised four different cultivars (PIWI-cultivars 'Calandro' and 'Regent' and the traditional cultivars 'Pinot Noir' and 'Riesling'), and GLSD-symptoms had been observed only rarely on these vines in previous years. Plant protection measures were integrated in vineyard " $A$ " and organic in " $B$ ". 
Monitoring of arthropods on vine pruning wounds and trunks

A preliminary survey was conducted in April 2019 to monitor arthropods visiting pruning wounds. One camera (Raspberry Pi 3 Model B V1.2, Raspberry Pi Foundation) was installed next to each pruning wound (pruning had been performed in February) on trunks of four different vines in vineyard "A" (Figure 1A). Images were captured every $5 \mathrm{sec}$ for $24 \mathrm{~h}$, and these were subsequently assessed for visiting arthropods. Visual surveys of vines were also carried out at 2 week intervals during the collection of arthropods from cardboard traps.

Assessment of arthropod diversity on vine trunks using cardboard traps

Traps were made from strips of corrugated cardboard (approx. $25 \times 60 \mathrm{~cm}$ ), and these were each wrapped twice around the trunk of each monitored vine (Moyo et al., 2014; Figure 1B). Twelve traps were placed randomly on trunks in vineyards " $A$ " and " $B$ ", with three traps used for each of the four cultivars in vineyard “B”. During wintertime (November to March), no arthropods were visible in preliminary inspections, so the traps were mounted by early April when temperatures were moderate and arthropods were first observed. Trapping was then continued until the end of October in 2019, and also to the end of November in 2020. Every second week, traps were each emptied into a large plastic box and arthropods were individually transferred with sterile forceps into sterile $2 \mathrm{~mL}$ capacity reaction

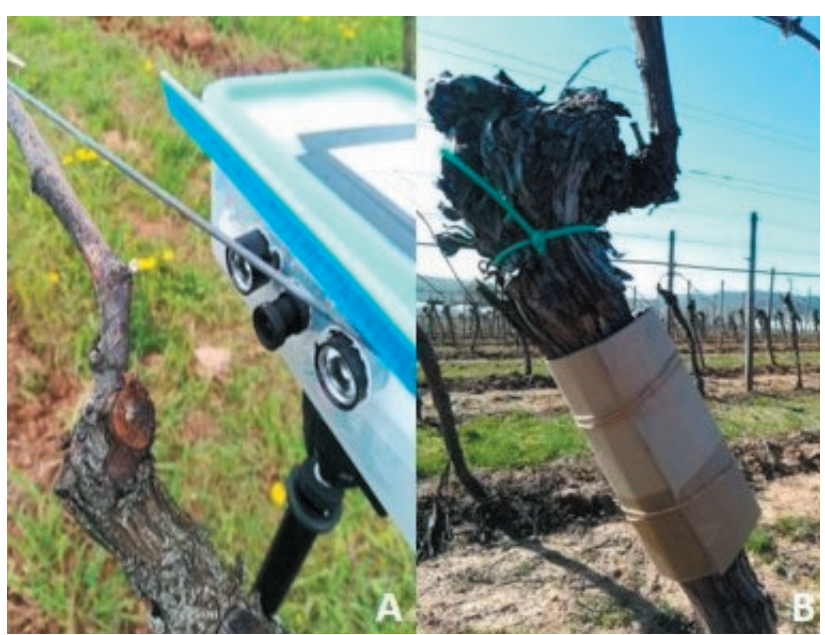

Figure 1. Camera focused on pruning wounds (A), and cardboard trap mounted around a grapevine trunk (B), used to monitor insects on grapevines. tubes. Due to the high number of European earwigs (Forficula auricularia L.), five individuals were pooled into a small glass container and were considered as one sample. A maximum of five such samples was taken per trap. Springtails (collembolans) from the same trap were also pooled into $2 \mathrm{~mL}$ capacity reaction tubes using a vacuum cup. Arthropods were morphologically identified using an identification guide for German fauna (Schaefer, 2017) and spiders were identified using a field guide for spiders (Roberts, 1995).

\section{Washing of arthropod exoskeletons and DNA extractions}

For detection of esca-related pathogens on arthropod exoskeletons, the protocol of Moyo et al. (2014) was followed, with modifications. Arthropods transferred into reaction tubes were freeze-killed at $-20^{\circ} \mathrm{C}$ for $1-2 \mathrm{~h} .1 .5 \mathrm{ml}$ of sterile distilled water was then added to each tube, and the tubes were vortexed for $60 \mathrm{sec}$. Washing suspensions containing possible fungal material were transferred into sterile $1.5 \mathrm{~mL}$ capacity reaction tubes, and arthropods were stored in $80 \%$ ethanol for later identification.

DNA extractions from the washing suspensions were carried out using the protocol of Tillet and Neilan (2000), with modifications. Tubes with washing suspensions were centrifuged at $15,000 \mathrm{rpm}$ for $10 \mathrm{~min}$ and the supernatant was discarded. Two 3-mm steel beads, 750 $\mu \mathrm{L}$ XS-buffer and $50 \mu \mathrm{L}$ cold TE-buffer were then added to the tubes. Samples were then placed in a tissue-lyser (Tissue Lyser 2; Qiagen) for $3 \mathrm{~min}$ at 30,000 $\mathrm{Hz}$, and were then incubated for $1 \mathrm{~h}$ at $70^{\circ} \mathrm{C}$ in a thermomixer (ThermoMixer comfort; Eppendorf AG) at $350 \mathrm{rpm}$. Samples were vortexed for $10 \mathrm{sec}$ and then put on ice for $30 \mathrm{~min}$ prior to centrifugation at $14,000 \mathrm{rpm}$ for 10 min. Supernatant $(700 \mu \mathrm{L})$ from each sample was then transferred into a new $1.5 \mathrm{~mL}$ capacity reaction tube and $700 \mu \mathrm{L}$ of ice cold $80 \%$ isopropanol was added. For DNA precipitation, samples were incubated at room temperature for $15 \mathrm{~min}$ prior to centrifugation at $10,000 \mathrm{rpm}$ for $10 \mathrm{~min}$. The supernatant from each sample was discarded and the DNA pellet was then washed with 250 $\mu \mathrm{L}$ of ice cold ethanol. After another centrifugation step at 10,000 rpm for $10 \mathrm{~min}$, the ethanol was discarded and the DNA pellet was air dried. The DNA was then resuspended in $30 \mu \mathrm{L}$ of TE-buffer and left overnight at $4^{\circ} \mathrm{C}$.

\section{Detection of esca-related pathogens using nested multiplex} PCR

DNA extracted from washing suspensions was subjected to a nested PCR. In primary PCR reactions, 
primers ITS5 and ITS4 (White et al., 1990) were used to amplify fungus-specific DNA. In secondary PCRs, Pch-specific primers Pch1H: 5'-CCC GAT CTC CAA CCC TTT GTT T-3' and Pch2H: 5'-CGG GCC TAT CTT CTA TGA AAG-3' (Haag, 2018), Pm spp.-specific primers Pm5H: 5'-GGA GGG CAC AGA CTC TGT ATT-3' and Pm3H: 5'-GTA AAC TAC TGC GCT CGG AG-3' (Haag, 2018) and Clo-specific primers CLO1F: 5'-TAC TAG AGC AAA GGA CAG GCA GC-3' (Navarette et al., 2011) and Clo3H: 5'-GAA CCC CAA TAC CAA GCG AGA G-3' (Haag, 2018) were used. All primers had final concentrations of $0.2 \mu \mathrm{M}$. PCR reactions were carried out in a SimpliAmp ${ }^{\text {tw }}$ Thermal Cycler (Applied Biosystems). The primary reactions were each carried out with SuperHot Taq DNA Polymerase (Genaxxon BioScience $\mathrm{GmbH}$ ) in a reaction volume of $25 \mu \mathrm{L}$, according to the user manual, and $1 \mu \mathrm{L}$ of the extracted DNA was used as template. The conditions of the primary reactions were as follows (Haag, 2018): initial denaturation at $95^{\circ} \mathrm{C}$ for $10 \mathrm{~min} ; 25$ cycles $30 \mathrm{sec}$ at $95^{\circ} \mathrm{C}, 30 \mathrm{sec}$ at $57^{\circ} \mathrm{C}$ and $30 \mathrm{sec}$ at $72^{\circ} \mathrm{C}$; final extension for $10 \mathrm{~min}$ at $72^{\circ} \mathrm{C}$. After the primary PCR, the reaction was diluted 1:50 with "BioScience-Grade" water (Roth) and $1 \mu \mathrm{L}$ of the dilution was used for the secondary PCR reaction conducted with the KAPA2G Fast Multiplex PCR Kit (Kapa Biosystems). Each reaction was carried out in a total volume of $10 \mu \mathrm{L}$ and was composed as advised in the user manual. Parameters were (Haag, 2018): initial denaturation at $95^{\circ} \mathrm{C}$ for $3 \mathrm{~min} ; 10$ cycles at $95^{\circ} \mathrm{C}$ for $15 \mathrm{sec}, 30 \mathrm{sec}$ at $69^{\circ} \mathrm{C}$ and $30 \mathrm{sec}$ at $72^{\circ} \mathrm{C} ; 25$ cycles at $95^{\circ} \mathrm{C}$ for $15 \mathrm{sec}, 30 \mathrm{sec}$ at $60^{\circ} \mathrm{C}$ and $30 \mathrm{sec}$ at $72^{\circ} \mathrm{C}$; final extension at $72^{\circ} \mathrm{C}$ for $3 \mathrm{~min}$. PCR products were loaded on a $2 \%$ agarose gel and run at $6 \mathrm{~V} / 5 \mathrm{~cm}$ for $1.5 \mathrm{~h}$. PCR products were visualized under ultraviolet (UV) light using a QUANTUM ST5 gel documentation system (Vilber Lourmat). A 100 bp ladder (New England Biolabs) marked the molecular size of the PCR- products, which were $433 \mathrm{bp}$ for Clo, $381 \mathrm{bp}$ for Pch and approx. $330 \mathrm{bp}$ for $\mathrm{Pm}$ spp.

\section{RESULTS}

Monitoring of arthropods on vine pruning wounds and trunks

Monitoring in April 2019 only rarely detected arthropods. In total, six arthropod orders were documented, including spiders, mites, bugs, ants, nocturnal centipedes and woodlice (Figure 2). Visual surveys of vine trunks frequently revealed ants (Temnothorax; Formicidae: Myrmicinae, or Lasius niger L., Formicidae: Formicinae) moving up and down the trunks during sunny weather, as well as red velvet mites (Allothrombium fuliginosum Hermann, Acari: Trombidiidae). Spider webs were often observed inside vine crevices, and from the end of May onwards, earwigs were sometimes observed within cracks in the bark.

Arthropod diversity on vine trunks assessed with cardboard traps

In 2019 and 2020, and from all sampling sites, a total of 2099 arthropods, assigned to 22 families, were collected from the cardboard traps. Significant families and the abundance of associated taxa are outlined in Table 1. Of all samples, approx. 30\% (640) were earwigs (Dermaptera: Forficulidae) and 27\% (568) were spiders (Aranea). Only one earwig species, the European earwig Forficula auricularia (L.) (Figure 3A), was found in the traps, and was the prevalent arthropod in vineyard "A". In many cases, more than 40 individuals were found in each cardboard trap. In contrast, spiders were the dominant arthropod order in vineyard "B". As the most

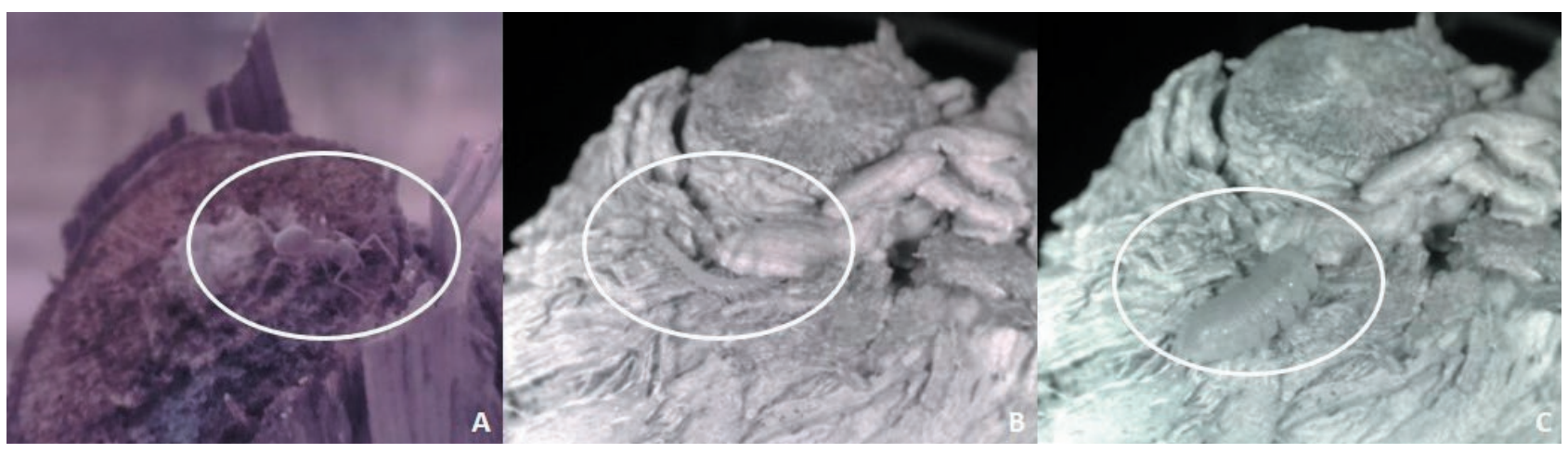

Figure 2. Images of arthropods visiting vine pruning wounds: A, an ant (Formicidae: Formicinae); B, a centipede (Chilopoda: Lithobiidae); C, a woodlouse (Isopoda: Armadillidiidae). 
diverse order, trapped spiders were of nine families, with $58 \%$ being Salticidae (jumping spiders), 10\% Gnaphosidae (ground spiders), 9\% Linyphiidae (sheet weavers) and $9 \%$ being Thomisidae (crab spiders). In total, 329 jumping spiders were trapped, of which $57 \%$ were Marpissa muscosa (Clerck) (Figure 3B), and 43\% were Synageles venator (Lucas) (Figure 3C). In vineyard "B", Raglius alboacuminatus (Goeze) (Heteroptera: Rhyparochromidae) (Figure 3D), a dirt-coloured seed bug, was frequently found (165). Only 23 individuals of this species were detected in vineyard "A", giving a total number of 188 (9\%) of this species from both vineyards and years. Thus, bugs, mainly $R$. alboacuminatus, were the third most common arthropod order. Woodlice were found irregularly in the traps, with a total number of 107 . Cockroaches, ants, springtails, harvestmen, centipedes, mites, millipedes and beetles were all collected in total numbers $<100$ (for species numbers see Table 1 ).

\section{Arthropods testing positive for esca-related pathogens}

Thirty-five percent of the 2099 arthropod samples tested positive for $\mathrm{Pch}, 21 \%$ for $\mathrm{Pm}$ spp. and 7\% for $\mathrm{Clo}$ (Table 1). For the predominant arthropod, the European earwig (640 samples), 27\% carried $P c h, 17 \%$ carried $P m$. spp. and $3 \%$ carried $\mathrm{Clo}$ on their exoskeletons. However, due to the pooling method applied for this species, these are maximum numbers, because pathogen-free individuals may have occurred side-by-side with positive individuals in a sample. For spiders, as the second most com-

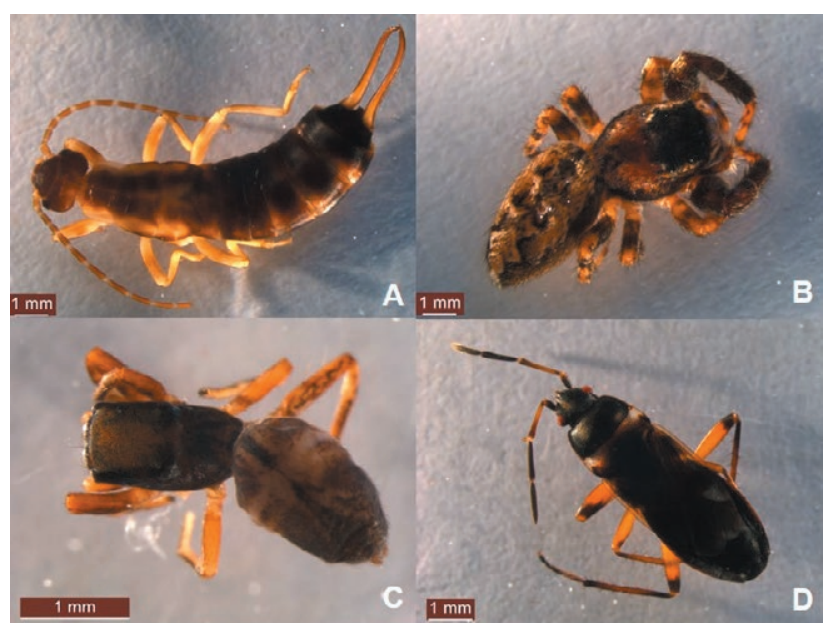

Figure 3. Most commonly found arthropods in cardboard-traps mounted to grapevine trunks in two vineyards: A, Forficula auricularia L. (Dermaptera: Forficulidae); B, Marpissa muscosa Clerck (Aranea: Salticidae); C, Synageles venator Lucas (Aranea: Salticidae); and D, Raglius alboacuminatus Goeze (Heteroptera: Rhyparochromidae). mon arthropod order (568 samples), 38\% were positive for Pch, 19\% for Pm spp., and 8\% were positive for Clo. Pch was detected most frequently on mites (59\%) and centipedes (57\%), Pm spp. most frequently on millipedes (43\%) and centipedes (40\%), and Clo most frequently on woodlice $(31 \%)$.

The rates of $P c h$-positive arthropods were very similar for vineyards "A" and "B", at, respectively, $36 \%$ and $35 \%$. Above average in vineyard "A" were bugs, woodlice and mites (respectively, 56\%, 51\% and 67\%). In vineyard "B", $42 \%$ of ants tested positive for Pch. The rate of arthropods carrying $P m$ spp. was greater in vineyard " $\mathrm{A}$ " $(25 \%)$ than in "B" (16\%). In vineyard "A", greatest rates for $P m$ spp. were found from spiders (30\%), bugs (37\%), cockroaches $(41 \%)$, mites $(42 \%)$ or beetles $(30 \%)$, while this was greatest for woodlice $(36 \%)$ in vineyard " $\mathrm{B}$ ". The proportions of Clo-positive arthropods was very similar in both vineyards, at $6 \%$ in vineyard " $\mathrm{A}$ " and $7 \%$ in vineyard "B". Very high numbers of woodlice $(48 \%)$ and harvestmen $(23 \%)$ were found in vineyard " $\mathrm{B}$ ".

Some arthropods tested positive for more than one esca-related pathogen (Table 2). Of 2099 surveyed arthropods, $12 \%$ carried both Pch and Pm spp., 1\% carried $\mathrm{Pch}$ and $\mathrm{Clo}, 1 \%$ carried $\mathrm{Clo}$ and $\mathrm{Pm}$ spp., and 2\% carried all three pathogens. Nine percent of earwigs, $10 \%$ of spiders and $11 \%$ of bugs tested positive for both $P c h$ and $P m$ spp. For arthropods collected in smaller numbers, the greatest rates of detection for the combination $P c h$ and $P m$ spp. were from centipedes (36\%), mites $(30 \%)$ and millipedes (20\%).

Occurrence of positive arthropods during the period of putative pruning wound susceptibility

Figure 4 presents an overview of arthropods that carried at least one of the esca-related pathogens during the sampling periods of April through June in 2019 and 2020. In both years, first occurrence of arthropods was noted at the beginning of April, with increasing numbers over the following months. In April, cumulated over both years and vineyards, spiders were the predominant arthropod order and 35\% (30 of 85) tested positive for esca-related pathogens. Ants, as the second most common arthropods, were positive in $41 \%$ (12 out of 29) of their captures. The numbers of samples of all other arthropods was $<20$. In May, spiders were still the most common arthropod order and 52\% (35 out of 67) of the captures tested positive for esca pathogens. The first earwigs were found in the same month and 37\% (22 of 59) carried esca-related pathogens. Ants and cockroackes had pathogen-positive proportions of 52\% (14 of 27) in May. By June, earwigs had replaced spiders as the pre- 


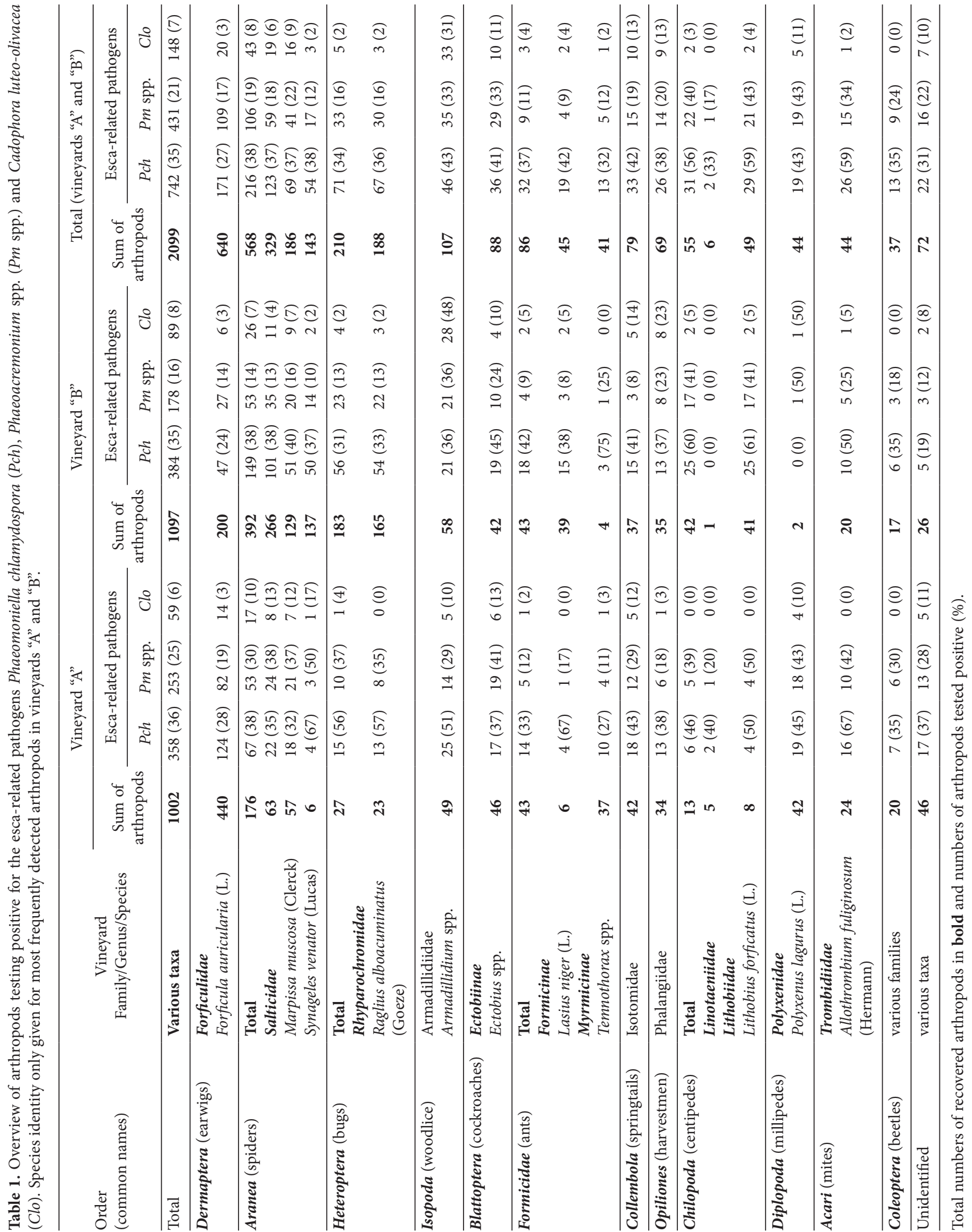


Table 2. Overview of arthropods testing positive for more than one of the esca-related pathogens Phaeomoniella chlamydospora (Pch), Phaeoacremonium spp. (Pm spp.) and Cadophora luteo-olivacea ( $\mathrm{Clo}$ ). Species identity only given for most frequent and representative arthropods.

\begin{tabular}{|c|c|c|c|c|c|c|}
\hline \multirow{2}{*}{$\begin{array}{l}\text { Order } \\
\text { (common names) }\end{array}$} & \multirow[b]{2}{*}{ Family/Genus/Species } & \multicolumn{5}{|c|}{ Esca-related pathogens (combinations) } \\
\hline & & $\begin{array}{c}\text { Sum of } \\
\text { arthropods }\end{array}$ & $\begin{array}{l}P c h+P m \\
\text { spp. }\end{array}$ & $\mathrm{Pch}+\mathrm{Clo}$ & $\begin{array}{l}C l o+P m \\
\text { spp. }\end{array}$ & $\begin{aligned} P c h & + \text { Pm spp. } \\
& + \text { Clo }\end{aligned}$ \\
\hline Total & Various taxa & 2099 & $248(12)$ & $28(1)$ & $18(1)$ & $46(2)$ \\
\hline \multirow{2}{*}{ Dermaptera (earwigs) } & Forficulidae & & & & & \\
\hline & Forficula auricularia (L.) & 640 & $58(9)$ & $6(1)$ & $2(0)$ & $6(1)$ \\
\hline \multirow{4}{*}{ Aranea (spiders) } & Total & 568 & $57(10)$ & $11(2)$ & $7(1)$ & $8(1)$ \\
\hline & Salticidae & 329 & $31(9)$ & $5(2)$ & $4(1)$ & $4(1)$ \\
\hline & Marpissa muscosa (Clerck) & 186 & $22(12)$ & $4(2)$ & $2(1)$ & $4(2)$ \\
\hline & Synageles venator (Lucas) & 143 & $8(6)$ & $1(1)$ & $2(1)$ & $0(0)$ \\
\hline \multirow{3}{*}{ Heteroptera (bugs) } & Total & 210 & $23(11)$ & $1(0)$ & $0(0)$ & $4(2)$ \\
\hline & Rhyparochromidae & & & & & \\
\hline & Raglius alboacuminatus (Goeze) & 188 & $22(12)$ & $0(0)$ & $0(0)$ & $3(2)$ \\
\hline \multirow{2}{*}{ Isopoda (woodlice) } & Armadillidiidae & & & & & \\
\hline & Armadillidium spp. & 107 & $16(15)$ & $1(1)$ & $3(3)$ & $10(9)$ \\
\hline \multirow{2}{*}{ Blattoptera (cockroaches) } & Ectobiinae & & & & & \\
\hline & Ectobius spp. & 88 & $17(19)$ & $1(1)$ & $1(1)$ & $2(2)$ \\
\hline \multirow{5}{*}{ Formicidae (ants) } & Total & 86 & $6(7)$ & $2(2)$ & $0(0)$ & $1(1)$ \\
\hline & Formicinae & & & & & \\
\hline & Lasius niger (L.) & 45 & $3(7)$ & $2(4)$ & $0(0)$ & $0(0)$ \\
\hline & Myrmicinae & & & & & \\
\hline & Temnothorax spp. & 41 & $3(7)$ & $0(0)$ & $0(0)$ & $1(2)$ \\
\hline Collembola (springtails) & Isotomidae & 79 & $8(10)$ & $3(4)$ & $1(1)$ & $4(5)$ \\
\hline Opiliones (harvestmen) & Phalangiidae & 69 & $9(13)$ & $0(0)$ & $1(1)$ & $3(4)$ \\
\hline \multirow{3}{*}{ Chilopoda (centipedes) } & Total & 55 & $20(36)$ & $0(0)$ & $0(0)$ & $2(3)$ \\
\hline & Linotaeniidae & 6 & $1(17)$ & $0(0)$ & $0(0)$ & $0(0)$ \\
\hline & Lithobiidae & 49 & $17(35)$ & $0(0)$ & $0(0)$ & $2(4)$ \\
\hline \multirow{2}{*}{ Diplopoda (millipedes) } & Polyxenidae & & & & & \\
\hline & Polyxenus lagurus (L.) & 44 & $9(20)$ & $0(0)$ & $1(2)$ & $4(9)$ \\
\hline \multirow{2}{*}{ Acari (mites) } & Trombidiidae & & & & & \\
\hline & Allothrombium fuliginosum (Hermann) & 44 & $13(30)$ & $1(2)$ & $0(0)$ & $0(0)$ \\
\hline Coleoptera (beetles) & Various families & 37 & $5(14)$ & $0(0)$ & $0(0)$ & $0(0)$ \\
\hline Unidentified & Various taxa & 72 & $7(10)$ & $2(3)$ & $2(3)$ & $2(3)$ \\
\hline
\end{tabular}

Total numbers of recovered arthropods in bold and numbers of arthropods tested positive (\%).

dominant group. They tested positive in $29 \%$ (39 of 134) of the cases, while $47 \%$ (24 of 51 ) of spiders carried esca pathogens. Of the cockraches, $77 \%$ (23 of 30 ) were pathogen-positive. The rate of positive ants had decreased to $29 \%$ (eight of 28).

\section{DISCUSSION}

Moyo et al. (2014) in South Africa were the first and, to date, the only authors to demonstrate possible involvement of arthropods in the dissemination of
GTD-, more precisely, esca-related pathogens. Arthropod mediated dispersal of these pathogens was previously suggested when T. minima (teleomorph of Pm. minimum) was detected on mites and termites found on symptomatic grapevines (Eskalen et al., unpublished, in Rooney-Latham et al., 2005a), and when Pm. rubrigenum was isolated from bark beetles in Czechia (Kubátová et al., 2004). Accumulation of collembolans and mites in grapevine cracks around sporulating mycelium of Pch was repeatedly observed by Edwards et al. (2001). As esca-related pathogens were frequently documented on arthropod exoskeletons in the present study of Ger- 

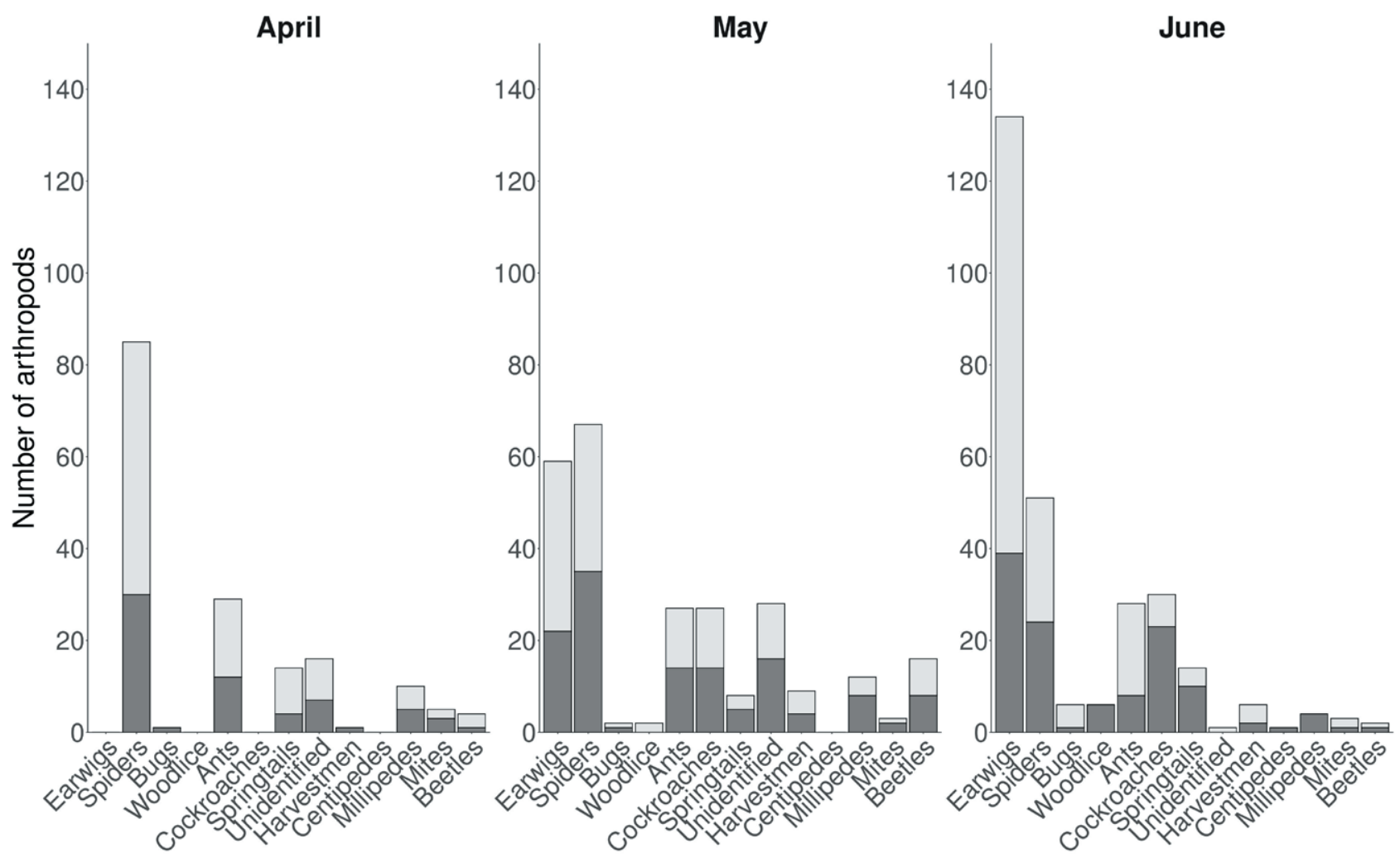

\section{Detection of esca-pathogens via PCR $]$ negative $]$ positive}

Figure 4. Arthropods testing negative or positive for esca-related pathogens in April, May and June of 2019 and 2020. Arthropods were collected from two different vineyards at 2 week intervals using cardboard traps mounted to grapevine trunks.

man vineyards, this confirms broad geographical indication that arthropods may be vectors for GTD pathogens.

In contrast to the study of Moyo et al. (2014) in South Africa, the present study used cardboard traps applied only to grapevine trunks, with no traps directly mounted around pruning wounds, so only arthropods directly collected from trunks were surveyed. Nonetheless, it can be assumed that these arthropods were also active during foraging on pruning wounds. This was confirmed by the camera-mediated monitoring, which showed activity of arthropods on pruning wounds during the putative host susceptibility phase (Figure 2). Particular attraction of arthropods to these wounds, as demonstrated by Moyo et al. (2014), was not observed in the present study. While wound sap in German vineyards is usually evident each year for a few weeks from mid March, temperatures during the two survey periods at that time were too low for arthropods to become active.

Moyo et al. (2014) in South Africa examined 5,677 arthropods, and $13 \%$ of these tested positive for Pch and $18 \%$ for Pm spp. In contrast, the present study of 2,099 arthropods showed greater pathogen-positive proportions of $35 \%$ for Pch and $21 \%$ for Pm spp. Possible reasons for this discrepancy could be ages of the studied vineyards, the cultivars, and the overall weather conditions.

A broad range of $P m$ spp. plays roles in GTDs (Mostert et al., 2006; Gramaje et al., 2015; Baloyi et al., 2018). As several of these species, most commonly Pm. minimum, occur in German vineyards (Fischer and Kassemeyer, 2003; Fischer et al., 2016; Kraus et al., 2019), a genus-specific primer pair was used to verify their presence on arthropod exoskeletons. Following Pch on 35\% of the arthropods, $P m$ spp. were detected in $21 \%$ of washing suspensions. These results confirm that structures of both Pch (Crous and Gams, 2000) and Pm spp. (Mostert et al., 2003; Rooney-Latham et al., 2005a; Mostert et al., 2006) are suitable for the adhesion of conidia or mycelium fragments to arthropod exoskeletons. The present study is the first to investigate the roles of arthropods for dissemination of Clo. The low frequency of $\mathrm{Clo}$ on arthropod exoskeletons (7\%) cannot be explained, but agrees with previous reports of low Clo 
isolation rates from previous Germany-based studies (Fischer et al., 2016; Kraus et al., 2019).

In the sampled vineyards, the European earwig $F$. auricularia, was the predominant arthropod followed by different spider species. The increasing numbers of earwigs in German vineyards and beyond, and their putative status as beneficial insects is seen critically (Huth, 2011; Kehrli et al., 2012; Mohr, 2012). Our study reveals a possible involvement of earwigs in the dispersal of GTDs, as individuals were found to carry Pch (27\% of earwigs assayed), $\mathrm{Pm}$ spp. (17\%) and Clo (3\%). As well, 9\% of earwigs tested positive for both Pch and Pm spp. As the omnivorous earwigs can migrate over considerable distances during foraging, depending on food sources (Lamb, 1975), they are likely to incidentally disperse the pathogens over several vines, also by wandering across pruning wounds. However, the pathogenic relevance may still be low because earwigs were present each year in the surveyed vineyards only from the end of May onwards (see also Huth, 2011). This indicates that earwigs occurred outside the immediate pruning wound susceptibility phase. As the susceptibility of wounds declines with time (Eskalen et al., 2007; Van Niekerk et al., 2011; Elena and Luque, 2016), earwigs are likely to be relevant for late-pruned vines that are potentially susceptible to pathogens until May or June each year.

Besides pruning wounds, three other aspects relate to infection processes and/or disease epidemiology. i) Wounds, caused by vineyard management such as sucker removal, may also be entry points for earwig-mediated pathogen dispersal during the vegetative grapevine phase (Makatini, 2014). ii) Conidia and/or mycelium fragments adhering to the earwig exoskeletons may be spread within and between vines. iii) The faeces of omnivorous earwigs could also be inoculum sources, which is indicated by Pch spores maintaining germinability after gut passage of millipedes (Moyo et al., 2014). Whether earwigs feed on esca-related pathogens in the field, and to which amount the resulting faeces may be inoculum sources, remain to be determined.

The majority of spiders found on vine trunks (58\%) were Salticidae (jumping spiders) with two dominant species, M. muscosa and the myrmecomorphic S. venator which has been previously identified as a dominant salticid in vineyards (Havlová et al., 2015). In total, 37\% of jumping spiders tested positive for $P c h, 18 \%$ were positive for $\mathrm{Pm} \mathrm{spp}$., and 6\% were positive for $\mathrm{Clo}$, and 9\% of salticids carried both Pch and Pm spp. on their exoskeletons. Salticids are free-hunting spiders which are very active during warm and sunny weather, and most likely migrate between vines in search of prey (Stresemann, 1992; Roberts, 1995). The small size of the ant-like S. venator $(3-4 \mathrm{~mm})$ makes it likely that these spiders, during hunting, encounter fungal pathogens sporulating between cracks and crevices in vine bark (Edwards et al., 2001; Baloyi et al., 2013). In the experimental plots of the present study, spiders were already common in April each year, when late-pruned vines are most likely to still be susceptible to GTD pathogens. Salticids tested positive for esca-related pathogens in April (35\%), May (52\%) and June (47\%), which indicates a possible risk for pathogen dissemination. Moreover, $10 \%$ of all spiders tested positive for both Pch and Pm spp.

All other arthropods, i.e. bugs, woodlice, centipedes, millipedes, cockroaches, ants, springtails, harvestmen, mites and beetles, were not as common as earwigs and spiders. Based on these results, these arthropods are likely to only be of low importance as GTD pathogen dispersal agents. However, woodlice frequently tested positive for all three pathogens, with $43 \%$ testing positive for $P c h$, $33 \%$ for Pm spp. and 31\% for Clo., and 15\% of woodlice were also co-positive for Pch and Pm spp. As woodlice were not commonly found (a total of 107 over the two seasons), their significance as pathogen vectors remains unclear. Also $36 \%$ of the centipedes and $20 \%$ of the millipedes carried both Pch and Pm spp. on their exoskeletons. As for woodlice, few centipedes (55 over the two seasons) and millipedes (44) were found in the traps, and these two arthropods were especially rare during the presumed pruning wound susceptibility phase.

Ants, indicated as important vectors of esca pathogens in South Africa (Moyo et al., 2014), were infrequent during the sampling periods of the present study. However, they were more common during the presumed months of vine susceptibility, and $41 \%$ of these insects tested positive for the pathogens in April, 52\% were positive in May and 29\% were positive in June. Ants were repeatedly observed moving up and down the vines, and were also captured visiting pruning wounds by the cameras in April (Figure 2A). Total numbers were less than 30 per month, and, in contrast to the observations of Moyo et al. (2014) in South Africa, no particular attraction by these insects to wound sap was detected.

The present study results, during 2019 and 2020, revealed a possible relationship between many different arthropod orders and esca-related pathogens. The predominant earwigs and spiders, representing $57 \%$ of the arthropods caught in traps, may disseminate pathogens in German vineyards, while spiders were already numerous in the presumed host pruning wound susceptibility phase. Furthermore, $12 \%$ of all surveyed arthropods tested positive for both Pch and Pm spp., which indicated possible co-existence of the pathogens on individual vines or within the arthropod migration ranges. No par- 
ticular attraction of arthropods to the pruning wounds was noted, which may have been due to the lack of sap during the arthropod activity periods.

Under Central European conditions we therefore conclude that arthropods may be incidental vectors of GTD pathogens. These arthropods could spread pathogens between several vines, as the majority of examined arthropods migrate during foraging.

The present study has broadened understanding of the epidemiology of GTDs. However, accurate assessment of the arthropod contributions to pathogen dissemination remains to be achieved. Besides incidentally vectoring pathogen propagules to vine wounds, the spatial dissemination of esca-causing pathogens on and between grapevines is likely to increase inoculum sources.

Future studies should address several related aspects. i) The actual propagule loads and infection potential carried by frequently occurring arthropods should be evaluated, to assess the significance of these as efficient pathogen vectors. ii) The susceptibility phase of wounds at different periods after grapevine pruning should be evaluated in German vineyards, to determine the risks of arthropod-mediated pathogen spread. iii) The role of earwig faeces as inoculum sources in vineyards needs to be elucidated. As precautionary measures to prevent disease-spread through arthropods, the greening management in vineyards should be adequately adjusted; also, the application of appropriate pruning wound protection should possibly be increased. Usage of insecticides is not encouraged here.

\section{ACKNOWLEDGEMENT}

The authors thank the team of the Mycology Group at the Julius Kühn-Institute, Siebeldingen, for their support in the laboratory and field.

\section{LITERATURE CITED}

Baloyi M.A., Halleen F., Mostert L., Eskalen A., 2013. First report of Togninia minima perithecia on escaand Petri-diseased grapevines in South Africa. Plant Disease 97(9): 1247.

Baloyi M.A., Mostert L., Halleen, F., 2018. Pathogenicity of ten Phaeoacremonium species associated with esca and Petri disease of grapevine. Phytopathologia Mediterranea 57(3): 538-546.

Bertsch C., Ramírez-Suero M., Magnin-Robert M., Larignon P., Chong J., ... Fontaine F., 2013. Grape- vine trunk diseases: complex and still poorly understood. Plant Pathology 62(2): 243-265.

Brasier C.M., 1991. Ophiostoma novo-ulmi sp. nov., causative agent of current Dutch elm disease pandemics. Mycopathologia 115(3): 151-161.

Christen D., Schönmann S., Jermini M., Strasser R.J., Défago G., 2007. Characterization and early detection of grapevine (Vitis vinifera) stress responses to esca disease by in situ chlorophyll fluorescence and comparison with drought stress. Environmental and Experimental Botany 60(3): 504-514.

Crous P.W., Gams W., 2000. Phaeomoniella chlamydospora gen. et comb. nov., a causal organism of Petri grapevine decline and esca. Phytopathologia Mediterranea 39(1): 112-118.

Edwards J., Laukart N., Pascoe I.G., 2001. In situ sporulation of Phaeomoniella chlamydospora in the vineyard. Phytopathologia Mediterranea 40(1): 61-66.

Elena G., Luque J., 2016. Seasonal susceptibility of grapevine pruning wounds and cane colonization in Catalonia, Spain following artificial infection with Diplodia seriata and Phaeomoniella chlamydospora. Plant Disease 100(8): 1651-1659.

Eskalen A., Gubler W.D., 2001. Association of spores of Phaeomoniella chlamydospora, Phaeoacremonium inflatipes, and Pm. aleophilum with grapevine cordons in California. Phytopathologia Mediterranea 40: S429-S432.

Eskalen A., Feliciano A.J., Gubler W.D., 2007. Susceptibility of grapevine pruning wounds and symptom development in response to infection by Phaeoacremonium aleophilum and Phaeomoniella chlamydospora. Plant Disease 91(9): 1100-1104.

Fischer M., 2002. A new wood-decaying basidiomycete species associated with esca of grapevine: Fomitiporia mediterranea (Hymenochaetales). Mycological Progress 1(3): 315-324.

Fischer M., 2019. Grapevine trunk diseases in German viticulture. III. Biodiversity and spatial distribution of fungal pathogens in rootstock mother plants and possible relation to leaf symptoms. Vitis 58: 141-149.

Fischer M., Kassemeyer H.-H., 2003. Fungi associated with Esca disease of grapevine in Germany. Vitis 42(3): 109-116.

Fischer M., Schneider P., Kraus C., Molnar M., Dubois C., d'Aguiar D., Haag N., 2016. Grapevine trunk disease in German viticulture: Occurrence of lesser known fungi and first report of Phaeoacremonium viticola and P. fraxinopennsylvanicum. Vitis 55: 145156.

Fontaine F., Pinto C., Vallet J., Clément C., Gomes A.C., Spagnolo A., 2016. The effects of grapevine trunk 
diseases (GTDs) on vine physiology. European Journal of Plant Pathology 144(4): 707-721.

Gramaje D., Mostert L., Armengol J., 2011. Characterization of Cadophora luteo-olivacea and C. melinii isolates obtained from grapevines and environmental samples from grapevine nurseries in Spain. Phytopathologia Mediterranea 50: S112-S126.

Gramaje D., Mostert L., Groenewald J. Z., Crous P.W., 2015. Phaeoacremonium: from esca disease to phaeohyphomycosis. Fungal Biology 119(9): 759-783.

Gramaje D., Úrbez-Torres J.R., Sosnowski M.R., 2018. Managing Grapevine Trunk Diseases with respect to etiology and epidemiology: Current strategies and future prospects. Plant Disease 102(1): 12-39.

Haag N., 2018. Grapevine Trunk Diseases: Epidemiologie und Molekulardiagnose wichtiger Esca-Erreger während der Pflanzguterzeugung. PhD Thesis, University of Hohenheim, Germany, $123 \mathrm{pp}$.

Halleen F., Mostert L., Crous P.W., 2007. Pathogenicity testing of lesser-known vascular fungi of grapevines. Australasian Plant Pathology 36: 277-285.

Havlová L., Hula V., Niedobová J., 2015. Spiders of the vine plants in Southern Moravia. Acta Universitatis Agriculturae et Silviculturae Mendelianae Brunensis 63(5): 1471-1476.

Hofstetter V., Buyck B., Croll D., Viret O., Couloux A., Gindro K., 2012. What if esca disease of grapevine were not a fungal disease? Fungal Diversity 54(1): $51-67$.

Huth C.D., 2011. Untersuchungen zur Lebensweise und zur Populationskontrolle des Gemeinen Ohrwurms Forficula auricularia L. (Insecta, Dermaptera) in Rebanlagen. PhD Thesis, University of Mainz, Germany, $329 \mathrm{pp}$.

Kehrli P., Karp J., Burdet J.-P., Deneulin P., Danthe E., ... Linder C., 2012. Impact of processed earwigs and their faeces on the aroma and taste of 'Chasselas' and 'Pinot Noir' wines. Vitis 51(2): 87-93.

Kraus C., Voegele R.T., Fischer M., 2019. Temporal development of the culturable, endophytic fungal community in healthy grapevine branches and occurrence of GTD-associated fungi. Microbial Ecology 77(4): 866-876.

Kraus C., Damm U., Bien S., Voegele R.T., Fischer M., 2020. New species of Phaeomoniellales from a German vineyard and their potential threat to grapevine (Vitis vinifera) health. Fungal Systematics and Evolution 6: 139-155.

Kubátová A., Kolařík M., Pažoutová S., 2004. Phaeoacremonium rubrigenum - Hyphomycete associated with bark beetles found in Czechia. Folia Microbiologica 49(2): 99-104.
Lamb R.J., 1975. Effects of dispersion, travel, and environmental heterogeneity on populations of the earwig Forficula auricularia L.. Canadian Journal of Zoology 53: 1855-1867.

Larignon P., Dubos B., 1997. Fungi associated with esca disease in grapevine. European Journal of Plant Pathology 103: 147-157.

Larignon P., Dubos B., 2000. Preliminary studies on the biology of Phaeoacremonium. Phytopathologia Mediterranea 39(1): 184-189.

Leach J.G., 1940. Insect transmission of plant diseases. McGraw-Hill Book Company, Inc. New York and London, 615 pages.

Lecomte P., Darrieutort G., Liminana J.-M., Comont G., Muruamendiaraz A., ... Fermaud M., 2012. New insights into esca of grapevine: The development of foliar symptoms and their association with xylem discoloration. Plant Disease 96(7): 924-934.

Makatini G.J., 2014. The role of sucker wounds as portals for grapevine trunk pathogen infections. MSc Thesis, University of Stellenbosch, South Africa, 108 pages.

Mohr H.D., 2012. Farbatlas Krankheiten, Schädlinge und Nützlinge an der Weinrebe. 2nd edition. Eugen Ulmer KG, Stuttgart, Germany, 335 pages.

Molnar M., Voegele R.T., Fischer M., 2020. Grapevine trunk disease in German viticulture IV. Spreading of spores of the Esca related fungus Phaeomoniella chlamydospora and the occurrence of foliar esca-symptoms in German vineyards. Vitis 59: 63-69.

Mondello V., Songy A., Battiston E., Pinto C., Coppin C., ... Fontaine F., 2018. Grapevine Trunk Diseases: A review of fifteen years of trials for their control with chemicals and biocontrol agents. Plant Disease 102(7): 1189-1217.

Mostert L., Crous P.W., Groenewald J.Z., Gams W., Summerbell R.C., 2003. Togninia (Calosphaeriales) is confirmed as teleomorph of Phaeoacremonium by means of morphology, sexual compatibility and DNA phylogeny. Mycologia 95(4): 646-659.

Mostert L., Groenewald J.Z., Summerbell R.C., Gams W., Crous P.W., 2006. Taxonomy and pathology of Togninia (Diaporthales) and its Phaeoacremonium anamorphs. Studies in Mycology 54: 1-113.

Moyo P., Allsopp E., Roets F., Mostert L., Halleen F., 2014. Arthropods vector grapevine trunk disease pathogens. Phytopathology 104(10): 1063-1069.

Moyo P., Mostert L., Spies C.F.J., Damm U., Halleen F., 2018. Diversity of Diatrypaceae species associated with dieback of grapevines in South Africa, with the description of Eutypa cremea sp. nov. Plant Disease 102(1): 220-230.

Mugnai L., Graniti A., Surico G., 1999. Esca (black measles) and brown wood-streaking: Two old and elusive diseases of grapevines. Plant Disease 83(5): 404-418. 
Navarrete F., Abreo E., Martínez S., Bettucci L., Lupo S., 2011. Pathogenicitiy and molecular detection of Uruguayan isolates of Greeneria uvicola and Cadophora luteo-olivacea associated with grapevine trunk diseases. Phytopathologia Mediterranea 50: S166-S175.

Roberts M. J., 1995. Spiders of Britain \& Northern Europe. Collins field guide, Harper Collins Publishers, London, UK, 383 pages.

Rolshausen P.E., Úrbez-Torres J.R., Rooney-Latham S., Eskalen A., Smith R.J., Gubler W.D., 2010. Evaluation of pruning wound susceptibility and protection against fungi associated with grapevine trunk diseases. American Journal of Enology and Viticulture 61(1): 113-119.

Rooney-Latham S., Eskalen A., Gubler W.D., 2005a. Ascospore release of Togninia minima, cause of Esca and grapevine decline in California. Plant Health Progress 6: 16 (1).

Rooney-Latham S., Eskalen A., Gubler W.D., 2005b. Occurrence of Togninia minima perithecia in escaaffected vineyards in California. Plant Disease 89(8): 867-871.

Schaefer, M., 2017. Brohmer - Fauna von Deutschland. 24th edition. Quelle \& Meyer Verlag GmbH \& Co., Wiebelsheim, Germany, 765 pages.

Stresemann E., 1992. Exkursionsfauna von Deutschland. Band 1. Wirbellose (ohne Insekten). Volk und Wissen Verlag GmbH Berlin, Germany, 637 pages.

Surico G., Marchi G., Ferrandino F.J., Braccini P., Mugnai L., 2000. Analysis of the spatial spread of esca in some Tuscan vineyards (Italy). Phytopathologia Mediterranea 39(1): 211-224.

Surico G., Mugnai L., Marchi G., 2006. Older and more recent observation on esca: a critical overview. Phytopathologia Mediterranea 45: S68-S86.

Surico G., 2009. Towards a redefinition of the diseases within the esca complex of grapevine. Phytopathologia Mediterranea 48(1): 5-10.

Tillett D., Neilan A., 2000. Xanthogenat nucleic acid isolation from cultured and environmental cyanobacteria. Journal of Phycology 36: 251-258.

Travadon R., Lawrence D.P., Rooney-Latham S., Gubler W.D., Wilcox W.F., ... Baumgartner K., 2015. Cadophora species associated with wood-decay of grapevine in North America. Fungal Biology 119(1): 53-66.

Van Niekerk J.M., Halleen F., Fourie P.H., 2011. Temporal susceptibility of grapevine pruning wounds to trunk pathogen infection in South African grapevines. Phytopathologia Mediterranea 50: S139-S150.

Vasquez S. J., Gubler W.D., Leavitt G.M., 2007. Economic loss in California's table grape vineyards due to measles. Phytopathologia Mediterranea 46: 118.
White T. J., Bruns T., Lee S., Taylor J., 1990. Amplification and direct sequencing of fungal ribosomal RNA genes for phylogenetics. In: PCR Protocols: A Guide to Methods and Applications, (Innis M.A., Gelfand D.H., Sninsky J.J. \& White T.J, eds.). Academic Press, Inc., San Diego, CA, USA, 315-322. 